\title{
KUALITAS INTERNAL TELUR AYAM MB 402 YANG DIBERI RANSUM DENGAN IMBANGAN PROTEIN DAN ENERGI BERBEDA
}

\author{
Jerlania M. Arunde, Jein Rinny Leke*, S. Rimbing, L. Tangkau \\ Fakultas Peternakan Universitas Sam Ratulangi, Manado
}

\begin{abstract}
ABSTRAK
Penelitian ini bertujuan mempelajari kualitas internal telur ayam MB 402 yang diberi ransum dengan imbangan protein dan energi berbeda. Sebanyak 80 ekor ayam petelur MB 402 umu38 minggu dengan perlakuan yang diberikan yaitu (P1: 15\% protein, 2800 $\mathrm{kcal} / \mathrm{kg}$ energi metabolisme), (P2: 16\% protein, $2800 \mathrm{kcal} / \mathrm{kg}$ energi metabolisme), (P3: $17 \%$ protein, $2700 \mathrm{kcal} / \mathrm{kg}$ energi metabolisme) dan (P4: 18\%, protein 2700 $\mathrm{kcal} / \mathrm{kg}$ energi metabolisme). Rancangan menggunakan Rancangan Acak Lengkap (RAL) dengan 4 perlakuan dan 5 ulangan pada tiap-tiap perlakuan terdapat 4 ekor ayam petelur MB 402. Variabel penelitian adalah indeks putih telur, warna kuning telur, dan indeks kuning telur. Imbangan protein dan energi berbeda dalam ransum tidak memberikan pengaruh nyata $(\mathrm{P}>$ $0,05)$ terhadap indeks putih telur, warna kuning telur, dan indeks kuning telur. Kesimpulan penggunaaan imbangan protein dan energi dalam ransum dengan level $15 \%$ protein dan $2800 \mathrm{kcal} / \mathrm{kg}$ energi metabolis memberikan hasil yang baik.
\end{abstract}

Kata kunci: Ayam petelur MB 40, Imbangan rotein dan energi, Kualitas telur

\footnotetext{
*Kosepondensi (corresponding author) Email : rinileke@yahoo.com
}

\begin{abstract}
This study aims to study the internal quality of chicken eggs MB 402 feed with different protein and energy balance. A total of $80 \mathrm{MB} 402$ chicken aged 38 weeks with the treatment given ( $\mathrm{P} 1$ 15\% protein, $2800 \mathrm{kkcal} / \mathrm{kg}$ energy metabolisme), (P2: $16 \%$ protein, $2800 \mathrm{kcal} / \mathrm{kg}$ energy metabolisme), (P3: 17\% protein, 2700 $\mathrm{kcal} / \mathrm{kg}$ energy metabolisme) dan (P4: $18 \%$, protein $2700 \mathrm{kcal} / \mathrm{kg}$ energy metabolisme). The design used is a complete random design (RAL) with 4 treatment 5 replications in each treatment there were 4 MB 402 laying hens. Research variabeles include : egg yolk index, egg yolk colour, and egg white index. The results showed that the protein and energy balance in the ration had no real effect $(\mathrm{P}>0,05)$ to the color of the yolk, the index of the index of the yolk, and theo0 index of the egg whites. Conclusions the use of protein and energy balance in ration with level $15 \%$ protein and $2800 \mathrm{kcal} / \mathrm{kg}$ energy metabolise.
\end{abstract}

Keywords: laying hens MB 402, Protein and energy balance, Egg quality

\section{PENDAHULUAN}

Ayam ras petelur adalah jenis ayamayam unggul impor yang telah dimuliabiakkan untuk tujuan produksi tertentu. Ayam ras petelur dipelihara untuk memproduksi telur. Ayam mulai 
berproduksi pada umur 22 minggu dengan jumlah telur 250-300 butir per ekor per tahun dan puncak produksi sampai 20 bulan (Susilorini et al., 2008). Ayam petelur menghasilkan 5-7 butir telur per minggu dan dalam 1 hari memproduksi 1 butir telur. Produksi ayam ras petelur akan menurun sampai umurnya mencapai $1,5-2$ tahun hingga ayam tersebut tidak produktif lagi.

Telur ayam ras petelur paling umum dikonsumsi dan digunakan sebagai pangan sehari-hari (Siregar et al., 2012). Sebutir telur memiliki nilai gizi tinggi serta perpaduan antara protein dan energi yang seimbang.

Kuaitas telur merupakan standar penentu baik kualitas eksternal maupun kualita internal. Kualitas internal telur ayam meliputi: putih telur, kuning telur, dan warna kuning telur. Ransum yang bergizi sangat diperlukan oleh ayam petelur untuk pertumbuhan, produksi telur, dan kualitas telur. Ransum yang bergizi adalah ransum yang mengandung karbohidrat, protein, mineral, vitamin, sesuai dengan yang diperlukan oleh ayam petelur untuk menghasilkan kuning telur, warna kuning telur dan putih telur yang baik.

Protein merupakan asam-asam amino yang digunakan untukmembentuk jaringan-jaringan tubuh, pengganti jaringan yang aus, untuk berproduksi dankelebihannya diubah menjadi energi. Kebutuhan protein dan energi merupakan faktor penting dalam menentukan produktivitas ayam, produksi telur, konsumsi ransum dan efisien penggunaan ransum. Protein pada ayam petetelur yang sedang dalam masa bertelur membutuhkan protein cukup banyak karena telur-telur yang dihasilkan sebagian besar dibentuk dari bahan protein.

Ayam petelur juga membutuhkan kabohidrat, lemak, dan vitamin sebagai sumber energi dalam menjalankan aktivitas misalnya, unruk pertumbuhan, meningkatkan daya tahan tubuh, dan produksi telur. Bila dalam ransum mengandung sedikit energi, maka produksitelur akan terhambat. ayam ras petelur yang kekurangan energi dalam akan mengalami produksi telur merosot, dan telur yang dihasilkan kurang baik. Kekurangan energi menyebabkan sebagian kerangka karbon protein diubah menjadi energi. Jika kandungan energi ransum diubah maka, kandungan protein ransum diubah sesuai dengan proporsi perubahan kandungan energi. Apabila kebutuhan energi terpenuhi, ayam akan berhenti mengkonsumsi ransum, sebaliknya konsumsi ransum meningkat bila kebutuhan energi terpenuhi. Apabila protein dalam ransum tinggi, maka energi dalam ransum harus ditingkatkan. Jika terjadi penurunan konsumsi akibat dari energi pada ransum yang melebihi ketentuan atau tinggi, maka protein dalam 
ransum harus seimbang (Harms et al., 2000).

Adapun uraian diatas maka dari itu dilakukan penelitian tentang kualitas internal telur ayam MB 402 yang diberi ransum dengan imbangan protein dan energi berbeda.

\section{MATERI DAN METODE PENELITIAN}

Penelitian ayam ras petelur fase layer MB 402 memakai ayam petelur umur 38 minggu, sebanyak 80 ekor. Penelitian menggunakan Kandang battery dengan ukuran 37x40x30 cm, Pakan yang diberikan pada ayam petelur MB 402 dalam penelitian adala jagung kuning, dedak halus, kosentrat, tepung ikan dan mineral. Alat yang dipakai untuk membandingkan warna kuning telur, yaitu Colour fun, kaliper digital untuk mengukur tinggi putih telur dan kuning telur.

Penelitian ini menggunakan Rancangan Acak Lengkap (RAL) dengan 4 perlakuan 5 ulangan, dengan perlakuan sebagai berikut:

$\mathrm{P} 1=$ protein $15 \%+$ energi metabolis 2800 $\mathrm{kkal} / \mathrm{kg}$

$\mathrm{P} 2=$ protein $16 \%$ + energi metabolis 2800 $\mathrm{kkal} / \mathrm{kg}$

$\mathrm{P} 3=$ protein $17 \%$ + energi metabolis 2700 $\mathrm{kkal} / \mathrm{kg}$
$\mathrm{P} 4=$ prtein $18 \%$ + energi metabolis 2700 $\mathrm{kkal} / \mathrm{kg}$

Pemberian pakan perlakuan dilakukan selama 8 minggu (56 hari), sedangkan untuk pengujian kualitas internal telur dilakukan per minggu. Dalam setiap ulangan dan perlakuan untuk dianalisa diambil 2 butir telur. Sampel yang dikoleksi pada setiap minggu pada hari kamis selama 8 minggu setelah perlakuan, diambil perbutir dalam setiap perlakuan dan ulangan kemudian dibawah ke laboratorium untuk dianalisa. Adapun Pengamatan yang dilakukan pada karakteristik fisik yaitu telur ditimbang secara utuh, kemudian dicatat berat telur, panjang dan lebar. Setelah itu, diukur tinggi putih, tinggi kuning telur, lebar putih telur dan lebar kuning telur dengan kaliper digital. Komposisi ransum dalam penelitian dapat dilihat pada Tabel 1, 2, dan 3 .

Pengujian kualitas internal telur yaitu dilakukan per minggu. Prosedur pengambilan sampel yaitu telur yang sudah dikoleksi sebanyak 40 butir di bawah ke laboratorium THT (Teknologi Hasil Ternak) untuk dilakukan analisa. Diamati warna kuning telur menggunakan Roche Yolk Colour, kemudian diukur tinggi dan lebar kuning telur dan putih terlur menggunakan kaliper digital.

Yang diamati antara lain: 
Tabel 1. Komposisi Bahan Pakan Penyusun Ransum

\begin{tabular}{lllllll}
\hline & & & & & Energi \\
Bahan Pakan & Protein & Lemak & Serat Kasar & Ca & Pospor & Metabolis \\
\hline Jagung $^{1}$ & 8,8 & 3,9 & 2 & 0,02 & 0,28 & 3350 \\
Dedak $^{1}$ & 12 & 13 & 12 & 0,12 & 0,5 & 1630 \\
Tepung Ikan $^{1}$ & 60 & 9 & 1 & 5,5 & 0,3 & 2830 \\
CaCO $_{3}$ & & & & 0,29 & & \\
Konsentrat $^{2}$ & 29 & 10 & 7 & 3 & 2 & 2600 \\
\hline
\end{tabular}

Ket : ${ }^{1)}$ Hasil Perhitungan Komposisi Nutrisi Bahan Pakan NRC (1994)

${ }^{2)}$ Sumber PT. Japfa

Tabel 2. Komposisi Zat - Zat Makanan Ransum Percobaan

\begin{tabular}{lllll}
\hline Bahan Pakan & R1 & R2 & R3 & R4 \\
\hline Jagung & 60 & 55 & 50 & 45 \\
Dedak & 12 & 12 & 12 & 12 \\
Tepung Ikan & 5 & 5 & 5 & 5 \\
CaC03 & 4 & 4 & 4 & 4 \\
Konsentrat & 19 & 24 & 29 & 34 \\
Total & 100 & 100 & 100 & 100 \\
\hline
\end{tabular}

Tabel 3. Komposisi Ransum percobaan

\begin{tabular}{lllll}
\hline & $\mathrm{R} 1$ & $\mathrm{R} 2$ & $\mathrm{R} 3$ & $\mathrm{R} 4$ \\
\hline Protein \% & 15,23 & 16,24 & 17,25 & 18,26 \\
Lemak \% & 6,25 & 6,56 & 6,86 & 7,17 \\
Serat Kasar \% & 4,02 & 4,27 & 4,52 & 4,77 \\
Ca \% & 0,88 & 1,03 & 1,18 & 1,33 \\
P \% & 0,62 & 0,71 & 0,80 & 0,88 \\
Energi Metabolis (kka/g) & 2841,10 & 2803,60 & 2756,10 & 2728,60 \\
\hline
\end{tabular}

Ket : Hasil perhitungan berdasarkan komposisi zat - zat makanan Tabel 2 dan 3. 
1. Warna kuning telur (North dan Bell, 1992).

Warna kuning telur dapat dilihat dan diamati dengan cara membandingkan warna kuning telur dengan menggunakan Roche Yolk ColourFan pada skala 1-15

2. Indeks Kuning Telur

Perhitungan indeks kuning telur ditentukan dengan mengukur tinggi dan diameter kuning telur menggunakan caliper digital. Indeks kuning telur diperoleh hasilnya dengan menggunakan rumus (Muchtadi dan Sugiyono, 1992)

$$
\begin{aligned}
& \text { Indeks kuning telur }= \\
& \text { tinggi kuning telur }(\mathrm{mm}) \\
& \text { diameter kuning telur }(\mathrm{mm})
\end{aligned}
$$

3. Perhitungan indeks putih telur.

Dilakukan dengan mengukur tinggi albumen kental menggunakan caliper digital. Indeks putih telur dihitumg dengan rumus menurut (Muchtadi dan Sugiyono, 1992)

$$
\begin{gathered}
\text { Indeks putih telur } \\
=\frac{\text { tinggi putih telur }(\mathrm{mm})}{\text { diameter putih telur }(\mathrm{mm})}
\end{gathered}
$$

\section{Analisa Data}

Data-data yang diperoleh dihitung dengan menggunakan Rancangan Acak Lengkap (RAL) dengan 4 perlakuan dan 5 ulangan. Kemudian data dianalis dengan menggunakan Microsoft excel 2010.

\section{HASIL DAN PEMBAHASAN}

Pengaruh imbangan protein dan energi berbeda terhadap kualitas internal telur yaitu indeks putih telur, warna kuning telur, dan indeks kuning telur dapat dilihat pada Tabel 4.

\section{Imbangan Protein dan Energi berbeda Terhadap Warna Kuning Telur}

Nilai rata-rata yang diperoleh indeks kuning telur dapat dilihat pada Tabel 4 dengan nilai rata - rata perlakuan P1 $(10,41 \pm 0,236) \quad P 2 \quad(9,95 \pm 0,277), \quad P 3$ $(10,28 \pm 0,285)$, dan P4 (10,14 $\pm 0,255)$. Untuk melihat hasil dari pengaruh imbangan protein dan energi berbeda dalam ransum maka dilakukan analisis statistik. Imbangan protein dan energi berbeda dalam ransum tidak memberi pengaruh nyata $(\mathrm{P}>0,05)$ terlihat warna kuning telur pada masing-masing perlakuan dengan imbangan $15 \%$ protein dan $2800 \mathrm{kcal} / \mathrm{kg}$ energi metabolis dalam ransum dapat meningkatkan warna kuning telur. 

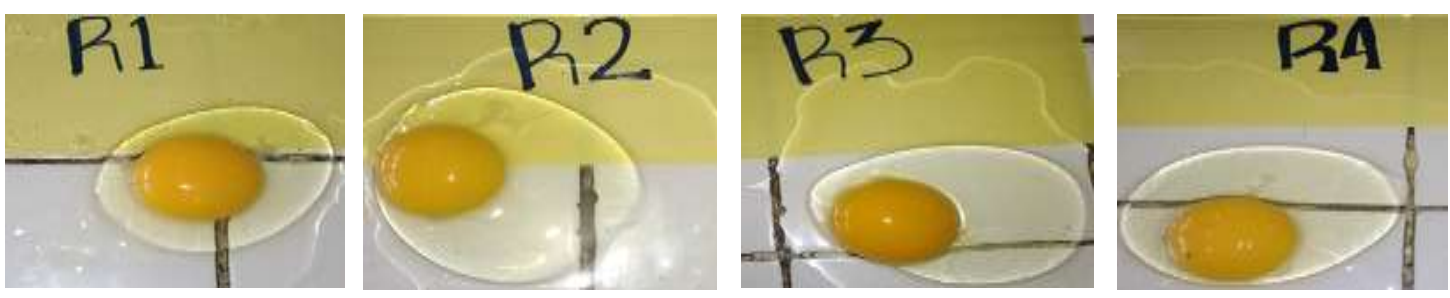

Gambar 1: Kualitas warna Kuning Telur Hasil Penelitian

Penggunaan jagung dalam ransum yang berfungsi sebagai sumber energi dan Xantophill. Xantophill inilah yang berpengaruh pada warna kuning telur bukan dari imbangan protein dan energi yang berbeda dalam ransum.

Jagung kuning memberikan warna pekat pada kuning telur karena jagung mempunyai pigmen karoten yang disebut "Xantophyll" Castellini et al. (2006). Karetonoid merupakan sumber pigmen pemberi warna yang berpengaruh langsung pada warna kuning telur (Sujana et al., 2008). Warna kuning telur ayam petelur memerlukan pigmen warna kuning yang berasal dari ransum, karena ternak tidak memproduksi pigmen warna tersebut.

\section{Imbangan Protein dan Energi berbeda Terhadap Indeks Kuning Telur}

Pada Tabel 4 dapat dilihat indeks kuning telur dari nilai rata - rata tiap perlakuan $\mathrm{P} 1, \mathrm{P} 2, \mathrm{P}$, dan $\mathrm{P} 4$ dari yang angka lebih tinggi hingga yang terendah yaitu $0,52 \pm 0,03 ; 0,49 \pm 0,01 ; 0,49 \pm 0,04$ dan 0,48 $\pm 0,02$. SNI (BSN, 2008) indeks kuning berkisar antara 0,33-0,52. Untuk melihat

Tabel 4. Pengaruh imbangan protein dan energi terhadap kualitas internal telur ayam MB 402

\begin{tabular}{lccc}
\hline \multirow{2}{*}{ Perlakuan } & \multicolumn{3}{c}{ Variabel } \\
\cline { 2 - 4 } & Warna Kuning Telur & Indeks Kuning Telur & Indeks Putih Telur \\
\hline P1 & $10,41 \pm 0,236$ & $0,52 \pm 0,03$ & $0,22 \pm 0.01$ \\
P2 & $9,95 \pm 0,277$ & $0,49 \pm 0,01$ & $0,23 \pm 0,00$ \\
P3 & $10,28 \pm 0,285$ & $0,49 \pm 0,04$ & $0,23 \pm 0,02$ \\
P4 & $10,14 \pm 0,255$ & $0,48 \pm 0,02$ & $0,23 \pm 0,01$ \\
\hline
\end{tabular}


hasil dari pengaruh imbangan protein dan energi berbeda dalam ransum maka dilakukan analisis statistik. Hasil dari imbangan protein dan energi berbeda adalah tidak memberi pengaruh nyata $(\mathrm{P}>0,05)$ pada indeks kuning telur.

Warna kuning telur yang hampir sama dihasilkan dari zat padat yang merupakan unsur pokok yaitu protein, sehingga kuning telur yang sama akan menghasilkan konsumsi relatif sama pula. Protein tersusun pada membrane vitelin dan khalaza berfungsi menjaga kekokohan kuning telur pada proses saat pembentukakan kuning telur. Protein pada pakan setiap perlakuan adalah salah satu faktor dalam mempengaruhi nilai indeks kuning telur. Keadaan ini sesuai dengan pendapat Agro et al. (2013), standar normal nilai indeks kuning telur yaitu berkisar 0,30-0,50 dengan rata-rata 0,42 . Nilai indeks kuning telur yang sama pada penelitian ini karena kandungan protein dan energi ransum yang hampir sama.

\section{Imbangan Protein dan Energi berbeda Terhadap Indeks Putih Telur}

Rata-rata nilai yang diperoleh dari tabel 4 pada indeks kuning telur secara berurutan dari $\mathrm{P} 1(0,22 \pm 0,01), \mathrm{P} 2(0,23 \pm 0)$ P3 $(0,23 \pm 0,02)$ dan P4 $(0,23 \pm 0,01)$. SNI (BSN, 2008) standar normal nilai indeks putih telur $0,050-0,174$. Dilakukan analisis statistik agar dapat mengetahui hasil dari imbangan protein dan energi yang berbeda.

Imbangan protein dan energi dalam ransum pada perlakuan ini adalah tidak memberi pengaruh nyata $(\mathrm{P}>0,05)$ terhadap indeks. Yuliansyah et al. (2015) protein dalam ransum mempengaruhi kualitas internal telur, secara umum mempengaruhi indeks putih telur. Lemak yang dipergunakan pada ternak merupakan hasil metabolisme yaitu karbohidrat, protein dan lemak untuk pembentukan telur dan reproduksi (Lestari et al., 2016). Kandungan protein dalam ransum yang diberikan merupakan gambaran dari putih telur atau albumin karna, nilai indeks putih telur bergantung pada protein ransum (Argo et al., 2013).

Jika terjadi penguapan gas $\mathrm{CO}_{2}$ dan air dalam telur akan terjadi kerusakan pada telur, karena adanya sifat basa dari putih telur akibat dari adanya ovomucin. Ovomucin terbuat dari bahan pakan yang tersidia dan dikonsumsi oleh ternak (Yuwanta, 2002). Untuk mempertahankan kualitas indeks putih telur, hal yang harus diutamakan adalah menjaga kekentalan putih telur. Faktor utama untuk mempengaruhi kekentalan putih telur adalah protein dalam ransum. 


\section{KESIMPULAN}

Penggunaan imbangan protein $15 \%$ dan energi $2800 \mathrm{kcal} / \mathrm{kg}$ pada perlakuan dalam pakan memberi indeks kuning telur, warna kuning telur, indeks putih telur yang baik

\section{DAFTAR PUSTAKA}

Argo, L. B., Tristiarti dan I. Mangisah. 2013. Kualitas ayam arab petelur fase I dengan berbagai level Azolla microphylla. Animal Agricultural Journal. 2(1): 445-447.

Castellini, C., F. Perella, C. Mugnai, and A. Dal Bosco. 2006. Welfare, productivity and quality traits off egg in laying hens reared under different rering systems. National Journal of Animal Science. 54(2): 147-155.

Harm, R.H., G.B. Russel, dan D.R. Sloan. 2000. Performance of four strains pf commercial layers with major changes in dietary energy. Journal of Applied Poultry Research 9: 535-541.

Lestari, W. T., S. Tana, dan S. Isdadiyanto. 2016. Indeks kuning telur dan nilai haugh unit telur puyuh (Coturnix co-turnix Japonica) hasil pemeliharaan dengan cahaya monokromatik. J. Buletin Anatomi dan Fisiologi 24(1): 42-49

Muchtadi, T.R. dan Sugiyono. 1992. Ilmu Pengetahuan Bahan Pangan. Petunjuk Laboratorium. Departemen Pendidikan dan Kebudayaan Direktorat Jendral
Pendidikan Tinggi Pusat Antar Universitas Pangan dan Gizi, Institut Pertanian Bogor.

National Research Council. 1994. Nutrient Requirements of Poultry. $9^{\text {th }}$ ed. National Academy Pr., Washington DC.

North, M. O. dan D. D. Bell. 1992. Commercial Chicken Production Manual. $4^{\text {th }}$ Edition. An AVI Book Published by Van Nostrand Reinhold, New York.

Siregar, F. R., A. Hintono, dan S. Mulyani. 2012. Perubahan Sifat Fungsional Telur Ayam Ras Pasca Pasteurisasi. Animal Agriculture Journal 1(1): 521-528.

Susilorini. E., M.E. Sawitri, Muharlien. 2008. Budidaya 22 Ternak Potensial. Penebar Swadaya, Jakarta.

Sudjana, Endang dan Wahyuni, Siti. 2008. Efek pemberian ransum yang mengandung tepung daun singkong, daun ubi jalar dan enceng gondok sebagai sumber pigmen karotenoid terhadap kualitas telur Itik Tegal. Jurnal Peternakan Fakultas Peternakan Universitas Padjajaran 8(5): 197-205

SNI (Standar Nasional Indonesia). 2008. Kumpulan SNI Bidang Pakan Direktorat Budidaya Ternak Non Ruminansia Direktorat Jendral Peternakan Departemen Pertanian Jakarta.

Yuwanta, T. 2002. Telur dan Kualitas Telur. Fakultas Peternakan. Universitas Gadjah Mada, Yogyakarta. 